\title{
OCCURRENCE OF TOXOPLASMA ANTIBODIES IN CAPRINE MILK AND SERUM IN EGYPT
}

\author{
M.A.M. ABDEL-RAHMAN ${ }^{*}$, SOHEIR M. EL-MANYAWE*, A.M. KHATEIB ${ }^{* *}$ and \\ SAHARE SABA ${ }^{* *}$ \\ *Parasitology Dept. ** (Beni-Suef branch) *** (Dokki branch). \\ Animal Health Research Institute, Agriculture Research Center, Giza, Egypt.
}

\section{ABSTRACT}

Received at:29/3/2012

Toxoplasma specific antibodies were identified in both serum and milk of naturally infected goats using Indirect Hemagglutination Test (IHAT). Samples were collected from a total of 182 goats in different localities of Greater Cairo, BeniSuif, and Zagazig regions, where both milk and serum samples were obtained from 73 lactating and only serum samples from109 non-lactating goats. Milk was investigated for the

Accepted: 22/4/2012 presence of $T$. gondii using experimentally infected cats. The results indicated that $77(42.30 \%)$ out of 182 were seropositive, where $38(34.86 \%)$ out of 109 non-lactating goats were seropositive for T.gondii antibodies using IHAT. Positive results were also indicated in 43(58.90\%), and 39(53.42\%) out of 73 lactating does in both milk and serum samples. Toxoplasma IgG and $\operatorname{IgM}$ antibodies were detected in 55(30.22\%) and $22(12.09 \%)$ out of 77 samples respectively. All experimentally infected cats fed on milk from acutely infected goats shed T.gondii oocysts, whereas only one out of 4 cats fed on milk from chronically infected goats shed T.gondii oocysts in their faeces. The public health importance due to consumption of raw or unpasteurized goat milk was discussed.

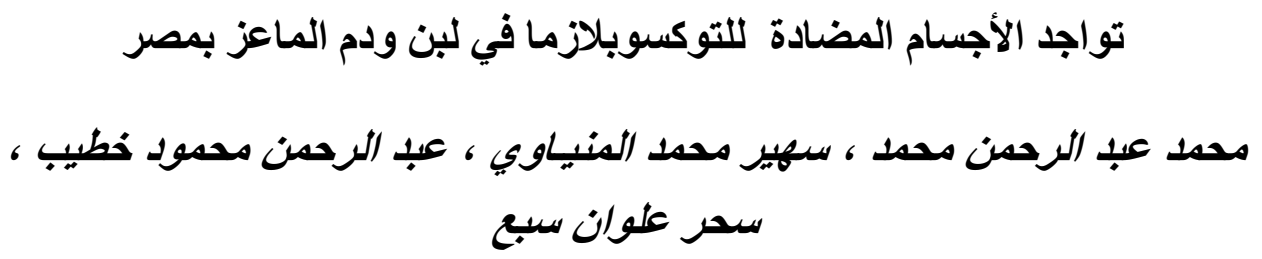

تم تحديد الأجسام المضادة الخاصة بالتوكسوبلازما في كل من مصل وحليب الماعز المصابة طبيعيا وذلك باستخدام اختبار

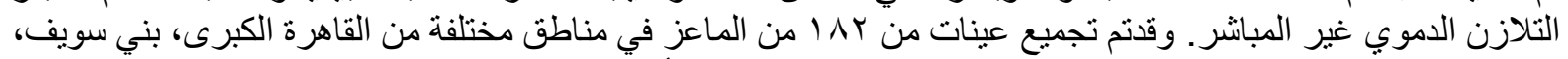

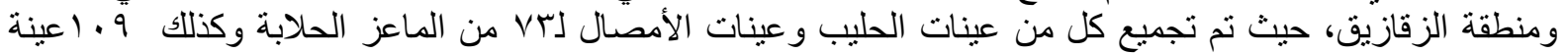

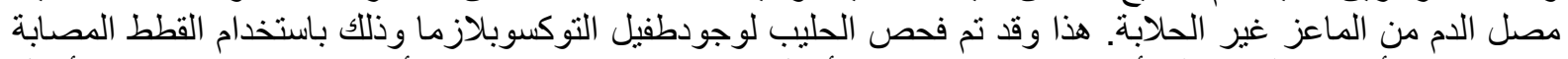

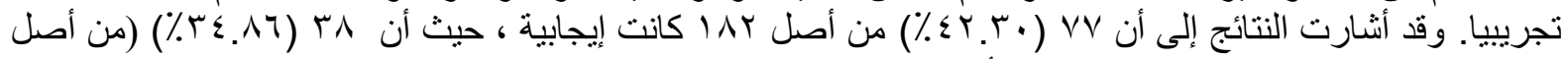

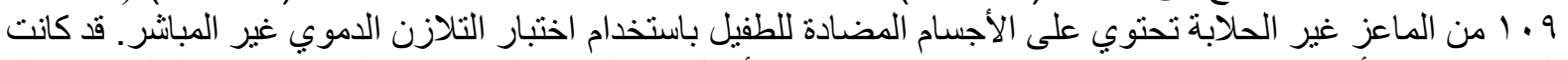

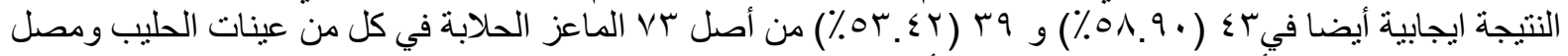

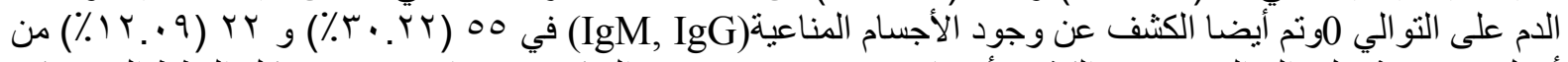

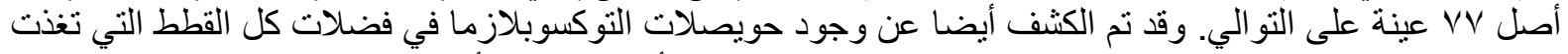

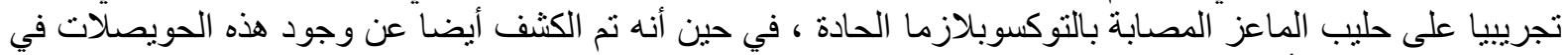

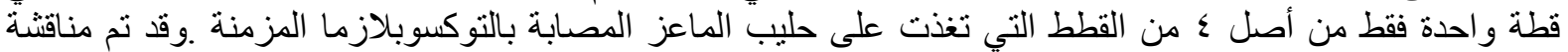

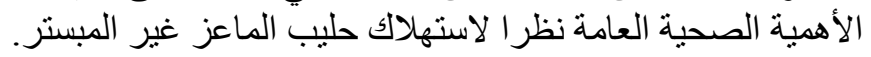


Key words: Toxoplasma gondii, Indirect Hemagglutination Test (IHAT), Caprine milk

\section{INTRODUCTION}

Toxoplasmosis, a coccidian infection, is caused by the obligate intracellular parasite Toxoplasma gondii. Although generally benign for healthy people, infection can result in stillbirth, blindness, mental retardation, and occasionally the death of congenitally infected infants (Frenkel, 1988). More recently, this disease has been observed in immunocompromised patients, particularly those with acquired immunodeficiency syndrome but also those with neoplastic disease and bone marrow or heart transplant recipients (Frenkel, 1988). In veterinary medicine, abortion and neonatal loss due to toxoplasmosis are of great economic importance in many parts of the world (Lautenslager, 1987). Goats infected by $T$. gondii represent an important source of human infection due to ingestion of meat and milk from infected animals. Such fact is extremely important concerning the disease control and mainly for public health, since the consumption of goat milk is elevated in children (Dubey, 1980). T. gondii tachyzoites were already isolated from milk of naturally infected goats as reported by Chiari and Neves (1984). Furthermore, an epidemiological survey showed that there was a statistically significant correlation between positive serology for $T$. gondii in humans and ingestion of goat milk (Chiari et al., 1987). The seroprevalence of $T$. gondii in goats has been surveyed in many countries, and these worldwide reports were recently summarized (Dubey, 2009). T.gondii-specific antibodies were identified in milk using IFAT (Azab et al., 1992) and ELISA (Haridy et al., 2010). However, IHAT was used by Masala et al. (2003), who detected that test is fast, accurate; and not expensive. Due to increasing exploration of goat herds and the risk for public health by ingestion of contaminated milk, the development of reliable and sensitive tests for diagnosing this zoonosis becomes very important. Thus, the aim of this study was to evaluate the IHAT to determine the seroprevalence of $T$. gondii infection in goat serum and milk as well as to demonstrate the presence of the organism in goat milk using experimentally infected cats.

\section{MATERIALS and METHODS}

\section{Collection of samples:-}

A total of 182goats over one year, were randomly selected from different herds in Greater Cairo, Beni-Suif, and Zagazig Governorates in Egypt. Blood samples were collected from all animals (lactating and non-lactating goats), where milk samples were collected from only 73 lactatin goats.

\section{1- Blood samples:}

About $3 \mathrm{ml}$ of blood were obtained via a jugular vein, in clean and dry test tubes, left to clot at room temperature and then centrifuged at $2000 \mathrm{r} / \mathrm{m}$ for 5 minutes. The separated sera were kept in sterile labeled tubes and stored at $-20^{\circ} \mathrm{C}$ until used.

\section{2- Milk samples:}

Milk samples were taken and collected in clean dry test tubes and rapidly frozen at $20^{\circ} \mathrm{C}$. Before use, all milk samples were centrifuged at $2000 \mathrm{r} / \mathrm{m}$ for $20 \mathrm{~min}$., and the interface between the lipid layer and the pelleted cellular debris was used (Grundy et al., 1983).

\section{Laboratory investigations:-}

Antibodies to $T$. gondii were determined in sera using an Indirect Hemagglutination Test (IHAT) with a commercially available kit (Toxo-IHA-Fast) obtained from ABC Diagnostics, New Domietta, Egypt. IHAT is fast, accurate, and not expensive and used mainly for diagnosis of T.gondii. (Hove et al., 2005). Antibodies titers of $\geq 1 / 80$ were considered positive for T.gondii.

In brief, sera were added to 96 well Ubottomed polystyrene plates, and diluted in a 
four-fold series from 1:40 to 1:2560, whereas, milk was used undiluted. The plates were shaken for 2 minutes and then incubated at $37^{\circ} \mathrm{C}$ for 2 hours without shaking. The test was considered positive when a layer of agglutinated erythrocytes was formed in wells at dilutions of 1:80 or higher, and positive and negative controls were included in each test. All reactive serum samples were treated with 2mercaptoethanol (2-ME) in order to verify the presence of IgM antibodies (Camargo et al., 1978).

\section{Experimental infection:}

Ten cats about one to two months of age were kept individually in cages and fed only boiled milk and bread. Faecal examinations were carried out daily for two weeks to insure that they were parasite free. Experimental animals were divided into three groups; four cats were fed fresh milk from acutely Toxoplasma infected goat, other four were fed fresh milk from chronically infected goat, and two were fed only boiled milk and bread as control group. Faecal samples from all animals were examined daily after five days of infection for one month using concentration flotation technique for detection of Toxoplasma oocysts according to Soulsby (1986). The detected oocysts were measured and kept in $2.5 \%$ potassium dichromate at $27^{\circ} \mathrm{C}$ for sporulation.

\section{RESULTS}

The prevalence of T.gondii in the serum and milk of examined goats were indicated in Table (1). The overall seroprevalence was $77(42.30 \%)$ out of 182 goats where 38 (34.86\%) out of 109 non-lactating goats and $39(53.42 \%)$ out of 73 lactating goats were positive for T.gondii using IHAT.

On the other hand, 43 milk samples (58.90 $\%)$ out of 73 had demonstrable T.gondii antibodies in the same lactating goats.

According to Table (2), the seropositive samples to T.gondii showed presence of IgG and $\operatorname{IgM}$ antibodies in 55(30.22\%) and $22(12.09 \%)$, respectively.

The antibody titers of IHAT ranged from $1 / 80$ to $1 / 2560$ in the sera of examined goats (Table 3).

Experimental infection in cats showed that only one cat out of 4 given milk from $\operatorname{IgG}$ seropositive goats (chronically infected) shed T.gondii oocysts 5 days post infection (d.p.i.), whereas all 4 cats given milk from IgM seropositive goats (acutely infected) shed T.gondii oocysts in their faeces 5-7 d.p.i. (Table 4).

Freshly excreted T.gondii oocysts measured $9-11 \mu \mathrm{m} \times 10-12 \mu \mathrm{m}$. sporulation time was 3 days at $27^{\circ} \mathrm{C}$. Sporulated and nonsoprulated T.gondii oocysts were shown in fig.1.

Table 1: Prevalence of $T$. gondii in the serum and milk of goats as determined by IHAT.

\begin{tabular}{cccccc}
\hline \multirow{2}{*}{ Animal } & \multirow{2}{*}{ Examined } & \multicolumn{2}{c}{ Serum } & \multicolumn{2}{c}{ Milk } \\
\cline { 3 - 6 } & & $(+\mathrm{ve})$ & $(\%)$ & $(+\mathrm{ve})$ & \\
\hline Non-lactating & 109 & 38 & $34.86 \%$ & - & $58.90 \%$ \\
\hline Lactating does & 73 & 39 & $53.42 \%$ & 43 & $58.90 \%$ \\
\hline Total & 192 & 77 & $42.30 \%$ & 43 & \\
\hline
\end{tabular}


Table 2: Seroprevalence of $T$. gondii antibodies in goats as determined byIHAT.

\begin{tabular}{cccccc}
\hline Examined & $(+\mathrm{ve})$ & $\operatorname{IgG}$ & $(\%)$ & $\operatorname{IgM}$ & $(\%)$ \\
\hline 182 & 77 & 55 & 30.22 & 22 & 12.09 \\
\hline
\end{tabular}

Table 3: Antibody titers in the serum of Toxoplasma infected goats using IHAT.

\begin{tabular}{cccccccc}
\hline Examined & $\begin{array}{c}\text { Total } \\
(+\mathrm{ve})\end{array}$ & $1 / 80$ & $1 / 160$ & $1 / 320$ & $1 / 640$ & $1 / 1280$ & $1 / 2560$ \\
\hline No. & 77 & 16 & 29 & 13 & 10 & 6 & 3 \\
\hline$(\%)$ & $42.30 \%$ & $20.7 \%$ & $37.7 \%$ & $16.9 \%$ & $13.0 \%$ & $7.8 \%$ & $3.9 \%$ \\
\hline
\end{tabular}

Table 4: Toxoplasma gondii oocysts excreted by cats experimentally infected by goat milk.

\begin{tabular}{lcccc}
\hline jource of milk & No. of cats & $(+\mathrm{ve})$ & $\begin{array}{c}\text { Prepatent } \\
\text { Period (days) }\end{array}$ & $\begin{array}{c}\text { Patent } \\
\text { Period (days) }\end{array}$ \\
\hline Chronic infection & 4 & 1 & 5 & 8 \\
\hline Acute infection & 4 & 4 & $5-7$ & $8-10$ \\
\hline Control (-ve) & 2 & - & - & - \\
\hline
\end{tabular}
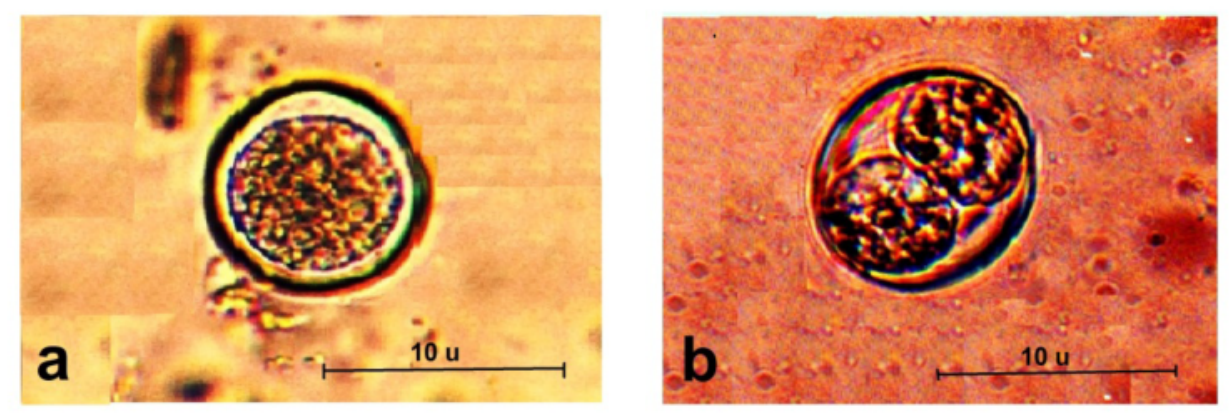

Fig.1: Toxoplasma gondii oocysts, nonsporulated (a), sporulated (a).

\section{DISCUSSION}

Toxoplasma gondii is an important zoonotic pathogen causing significant human and animal health problems. Infection in dairy goats not only results in significant reproductive losses, but also represents an important source of human infection due to consumption of infected meat and milk constituting zoonotic transmission (Sacks et al., 1982).

Serologic prevalence data indicate that infection is more common in warm climates and at lower altitudes than in cold climates and mountainous regions. High prevalence of infection in France has been related to a preference for eating raw or undercooked meat, while high prevalence in Central America has been related to the frequency of stray cats in a climate favoring survival of oocysts (Ciamak, 2006).

Caprine Toxoplasmosis was reported worldwide (Dubey, 1980; Masala et al., 2003 and Dubey, 2009). Even though few studies have been conducted on milk antibodies (Azab et al., 1992; Haridy et al., 2010), 
nothing is known about the detection of T.gondii in caprine milk in Egypt.

In the present study, the overall seroprevalence of T.gondii infection in goats was $42.30 \%$ using IHAT in Egypt. Similar observations were reported in Egypt (Ghoneim et al., 2010; El-Manyawe et al., 2001; Maronpot and Botros, 1972). The high positivity in IHAT suggest continuous exposure of goats to heavy environmental contamination with oocysts shed from stray cats, poor manage conditions, infected males, and the origin of the animals (Dubey, 1996).

The extent of toxoplasmosis in goat population varied from flock to flock around the world. Unlike our results, lower prevalence were recorded, $19 \%$ in Brazil (Josely et al., 2001), 14.1\% in China (Zhao et al., 2011), 27\% in Egypt (Abou Zeid et al., 2010). Such differences in prevalence may be attributed to diagnostic technique, demographic of goat population, breeding conditions and management (Masala et al., 2003), immune status, timing of infection and genetic composition of the host and the organism (Suzuki, 2000) or distribution and behavior of cats (Buxton, 1990).

Toxoplasma antibodies are detectable two weeks post infection and maintain a low level through the host's life (Lin and Bowman, 1991). Accordingly, testing for IgM antibodies which appear about one week post infection permitted recent infection. The results indicated that $55(30.22 \%)$ out of 77 goats had $\mathrm{IgG}$, whereas $22(12.09 \%)$ had IgM. This result also agreed with similar study in Italy (Masala et al., 2003). Such value of IgM indicates true infection with T.gondii (Camargo et al., 1978).

The antibodies titers of IHAT ranged from $1 / 80$ to $1 / 2560$ with the most frequent at $1 / 160$. This result agrees with those reported by AbouZeid et al. (2010) and El-Manyawe et al. (2010). High values of antibody titers can be ascribed to active toxoplasma infection as well as reactivation of infection due to immunosupressor conditions (Robert et al., 1981).

In the present study we confirmed IHAT on serum samples by application of the test on milk samples as milk antibodies were observed between 7-10 days post infection (Thierry et al., 1990). Toxoplasma antibodies were detected in the milk of naturally infected lactating women (Azab et al., 1992), in working donkeys (Haridy et al., 2010) and experimentally in mice (Thierry et al., 1990). The present study indicated that $53.42 \%$ of examined goats had demonstrable antibodies in both milk and serum samples. In fact, the majority of positive $(58.9 \%)$ were reactive in milk samples.

It has been shown that milk antibodies reflect local antigenic stimuli to the infection, such antibody detection might be of assistance in studies of the endemicity of the disease (Grundy et al., 1983). A comparison of milk and serum reactivity to T.gondiiis further complicated by the differences in immunoglobulin concentrations between individual milk samples as well as between milk and serum. In endemic areas the systemic antibody response may be boosted by repeated infections, and high-titer serum antibodies may persist for years even in the absence of continuous infection. Whereas the systemic response has a longer-lasting immunological memory, the local immunological memory is short lasting, although reinfection may boost memory of a somewhat longer duration. Therefore, although in an endemic area serum antibodies indicate past or present invasive disease, milk antibodies are more likely to suggest present or recent infection (Grundy et al., 1983). The presence of positive IgMin goat serum samples suggests recently acquired or active infection, demonstrating that these animals can constitute an important source of transmission to man, since they are able to present $T$. gondii tachyzoites in milk.

The organism was detected previously in the milk of experimentally infected cat (Powell et al., 2001), and rat (Costa and Langoni, 2010) both in chronic and acute infections.

Regarding to the comparison between serological results and experimental infection in cats, this study demonstrated that $T$. gondii was found in the milk of both chronically and acutely infected goats. All experimentally 
infected cats given milk from seropositive goats to IgM shed T.gondii oocysts, whereas only 1 out of 4 cats given milk from seropositive goats to $\operatorname{IgG}$ shed $T$. gondii oocysts in their feaces. So, there were complete concordance between $\operatorname{IgM}$ antibodies and experimental infection in cats.

The presence of the organism in the milk of chronically infected goats may be due to the resurgence of tissue $T$. gondii tachyzoites cysts which can circulate again and be excreted in the milk during the peripartum period. Similar results were obtained by Camossi et al. (2011).

Previous studies indicated that consumption of raw milk from infected goats represent a vehicle for transmission of toxoplasmosis as unpasteurized milk is considered an important food source in rural areas (Riemann et al., 1975 and Sacks et al., 1982). It is particularly important in infants than in adults. It has been shown that milk promoted higher infectivity and mortality, revealing probably better preservation or efficiency of T.gondii as milk nutrients maintains tachyzoites viable for longer time and protects them from gastric juice. So, milk could be considered a potential source of T.gondii transmission, especially in rural areas where there's no pasteurization (Gross et al., 1996).

Therefore, caprine toxoplasmosis deserves special attention of the public health organizations in order to advise the population on the real situation of the infection in the country through frequent serological surveys, since this disease often occurs as subclinical form in man and animals.

\section{REFERANCES}

AbouZeid, N.Z.; Amer, H.A.; Barakat, T.M.; Selim, A.M. and EL-Balkemey, F.A. (2010):

Toxoplasmosis in naturally and experimentally infected goats. J. Am. Sci. 6(11)122-129.

Azab, M.E.; Kamel, A.M.; Makled, K.M.; Khattab, H.; El-Zayyat, E.A.; Abo-Amer, E.A. and Samy, G. (1992): Naturally occurring toxoplasma antibodies in serum and milk of lactating women.J. Egypt. Soc. Parasitol. Aug; 22(2): 561568.

Buxton, D. (1990): Ovine toxoplasmosis: a review. Journal of the Royal society of Medicine, 83: 509-511.

Camargo, M.E.; Ferreira, A.W.; Mineo, J.R.; Takiguti, C.K. and Nakahara, O.S. (1978): Immunoglobulin $\mathrm{G}$ and immunoglobulin $\mathrm{M}$ enzyme-linked immunosorbent assays and defined toxoplasmosis serological patterns. Infect Immun 21: 35-38.

Camossi, L.G.; Greca-Júnior, H.; Corrêa, A.P.; Richini-Pereira, V.B.; Silva, R.C.; $D a$ Silva, A.V. and andLangoni, $H$. (2011): Detection of Toxoplasma gondii DNA in the milk of naturally infected ewes.Vet.Parasitol.May $\quad 11 ; 177(3-4)$ : 256-61.

Chiari, C.A. and Neves, D.P. (1984): Toxoplasmosehumanaadquiridaatravés da ingestão de leite de cabra. MemInstOswaldo Cruz 79: 337-340.

Chiari, C.A.; Lima, W.S.; Antunes, C.M.F. and Lima, J.D. (1987): Soroepidemiologia da toxoplasmosecaprinaem Minas Gerais, Brasil. Arq.Bras. Med. Vet. Zootec, 39: 587-609.

Ciamak, G. (2006): Serological survey of antibodies to Toxoplasma gondii. African Journal of Health Sciences, Volume 13, Number 1-2, 131-134.

Costa, V.M. and Langoni, H. (2010): Detection of Toxoplasma gondiiin the milk of experi-mentally infected Wistar female rats. J. Venom Anim. Toxins incl. Trop. Dis.;16(2): 369

Dubey, J.P. (2009): Toxoplasmosis of Animals and Humans. CRC Press Inc. Boca Raton, New York.

Dubey, J.P. (1980): Persistence of encysted Toxoplasma gondii in caprine levers and public health significance of toxoplasmosis in goats. J. Am. Vet. Med. Assoc. 15: 1203-1207.

Dubey, J.P. (1996): Strategies to reduce transmission of Toxoplasma gondii to animals and humans. Vet. Parasitol. 64: 65-70. 
El-Manyawe, S.M.; Abdel Rahman, M.A.; Abd El Aal, A.M.; Azza M. Kamal and Samira A. Snousi (2010): Influence of some protozoa on biochemical changes in goats in Cairo, Marsa Matrouh, and El-Wadi El-Gadidprovinces. Egypt. J. Comp. Path. 23(1): 102-115.

El-Manyawe, S.M.; Khattab, M.H. and Ismail, I. (2001): Serodiagnosis of Toxoplasma antibodies among sheep and goats in the North Coast of Egypt. Alex. J. Vet. Sci, 17(1) 35-45.

Frenkel, J.K. (1988): Pathophysiology of toxoplasmosis. Parasitol. Today 4: 273278.

Ghoneim, N.H.; Shalaby, S.I.; Hassanain, N.A.; Zeedan, G.S.; Soliman, Y.A. and Abdalhamed, A.M. (2010): Comparative study between serological and molecular methods for diagnosis of toxoplasmosis in women and small ruminants in Egypt. Foodborne Pathog Dis. Jan; 7(1): 17-22.

Gross, U.; Bohne, W.; Soête, M. and Dubremetz, J.F. (1996): Developmental different-iation between Tachyzoites and Bradyzoites of Toxoplasma gondii. Parasitol. Today; 12: 30-3.

Grundy, M.S.; Cartwright-Taylor, L.; Lundin, L.; Thors, C. and Huldt, G. (1983): Antibodies

AgainstEntamoebahistolytica in Human Milk and Serum in Kenya. J. Clinical Microbiology, p. 753-758.

Haridy, F.M.; Saleh, N.M. and Khalil, H.H. and Morsy, T.A. (2010): AntiToxoplasma gondii antibodies in working donkeys and donkey's milk in greater Cairo, Egypt. J. Egypt. Soc.Parasitol. Aug; 40(2): 459-464.

Hove, T.; Lind, P. and Mukaratirwa, S. (2005): Preliminary characterization of Toxoplasma gondii isolates from Zimbabwe with stage specific monoclonal antibodies. Annual of Tropical of Medical Parasitology. 99: 377-382.

Josely, F. Figueiredo; Deise, A.O. Silva; Dagmar, D. Cabral and José, R. Mineo (2001): Sero-prevalence of Toxoplasma gondii Infection in Goats by the Indirect Haem-agglutination,
Immunofluorescence

and Immunoenzymatic Tests in the Region of Uberlândia, Brazil. MemInst Oswaldo Cruz, Rio de Janeiro, Vol. 96(5) 687-692.

Lautenslager, J.P. (1987): Toxoplasmosis as a significant disease in man and animals with special reference to preventive measures by the farm community. Can. Vet. J. 28: 261-264.

Lin, D.S. and Bowman, D.D. (1991): Cellular response of cats with primary toxoplasmosis. J.Parasitol. 77: 272-279.

Maronpot, R.R. and Botros, A.M. (1972): Toxoplasma serologic survey in man and domestic animals in Egypt. J. Egypt. Public Health Assoc., 42: 58-67.

Masala, G.R.; Porcu, L.; Madau, A.; Tanda, Ibba, B.; Satta, G. and Tola, S. (2003): Survey of ovine and caprine toxoplasmosis by IFAT and PCR assays in Sardinia, Italy. Vet. Parasitol. 117: 15-21.

Powell, C.C.; Brewer, M. and Lappin, M.R. (2001): Detection of Toxoplasma gondii in the milk of experimentally infected lactating cats. Vet. Parasitol., 102(1-2): 29-33.

Riemann, H.P.; Meyer, M.E.; Theis, J.H.; Kelso, G. and Behymer, D.E. (1975): Toxoplasmosis in an infant fed unpasteurized goat milk. Journal of Pediatrics. 87 (4) 573-576.

Robert, R.; Chabasse, D. and Hocquet, P. (1981): Anti-Toxoplasma IgM studied by indirect immunofluorescence and hemagglutination elimination of false positives and negatives by adsorption of $\mathrm{IgG}$ on immobilized protein A. Biomedicine 35: 61-65.

Sacks, J.J.; Roberto, R.R. and Brooks, N.F. (1982): Toxoplasmosis infection associated with raw goat's milk. JAMA. 248: 1728-1732.

Soulsby, E.J.L. (1986): Helminths, arthropods, protozoa of domesticated animals. Bailliere, Tindall and Cassel, London, UK.

Suzuki, Y. (2000): Host resistance in the brain against Toxoplasma gondii. Journal of Infectious diseases, 185: 359-361. 
Thierry, C.; Isabelle bourguin; Marie-Noelle Mevelec; Jean-Francois Dubremetz and Daniel Bout (1990): Antibody Responses to Toxoplasma gondii in Sera, IntestinalSecretions, and Milk from Orally Infected Miceand Characterization of Target Antigens. Infectionand Immunity. 1240-1246
Zhao, G.H.; Zhang, M.T.; Lei, L.H.; Shang, C.C.; Cao, D.Y.; Tian, T.T.; Li, J.; Xu, J.Y.; Yao, Y.L.; Chen, D.K. and Zhu, X.Q. (2011): Seroprevalence of Toxoplasma gondii infection in dairy goats in Shaanxi Province, Northwestern China. Parasit. Vectors. 1, 4: 47. 